\title{
Penerapan Metode Curah Gagasan (Brainstorming) Untuk Meningkatkan Kemampuan Mengemukakan Pendapat Siswa
}

\author{
Oleh : Diyah Nur Fauziyyah Amin \\ Pendidikan Sejarah PPS UNJ
}

\begin{abstract}
Based on the observations made by researchers, there are four problems that occur in the classroom are: less of enthusiasm of the students in following the teaching of history, less of response to the student when giving responses and rebuttals, students are less active to ask and answer questions of teachers and teaching is also still using the approach teacher center. The method used is a method of classroom action research with four cycles. This classroom action research conducted in Man Cirebon 1 in class XI IPS 4. In the first cycle students have not implemented the method brainstorming well but, after investigator learned from the first cycle, the teacher gave them the motivation to reward, and the media that interest the students. The result in the second cycle, third and fourth categories of students' ability to express opinions is at a good level. because students are enthusiastic in identifying questions, looking for ideas or ideas, find an idea or ideas, formulate opinions and submit an opinion in the teaching of history.
\end{abstract}

Keywords: brainstorming, express opinions, and reward

Keyword: brainstorming, express opinions, and reward

\begin{abstract}
Abstrak
Berdasarkan pengamatan yang dilakukan oleh peneliti, ada empat masalah yang terjadi dalam kelas tersebut yaitu: kurang antusiasnya para siswa dalam mengikuti pembelajaran sejarah, kurang responnya siswa ketika memberikan tanggapan dan sanggahan, siswa kurang aktif untuk bertanya dan menjawab pertanyaan guru dan pembelajaran juga masih menggunakan pendekatan teacher center. Metode yang dilakukan adalah metode penelitian tindakan kelas dengan empat kali siklus. Penelitian tindakan kelas ini dilaksanakan di Man Cirebon 1 di kelas XI IPS 4. Pada siklus pertama siswa belum melaksanakan metode brianstorming dengan baik tetapi, setelah peneliti belajar dari siklus pertama, diantaranya guru memberikan motivasi dengan memberikan reward, dan membuat media yang menarik perhatian siswa. hasilnya pada siklus kedua,ketiga dan keempat kategori kemampuan mengemukakan pendapat siswa berada pada tingkatan baik. karena siswa antusias alam mengidentifikasi pertanyaan, mencari ide atau gagasan, menemukan ide atau gagasan, merumuskan pendapat dan mengajukan pendapat dalam pembelajaran sejarah.
\end{abstract}

Kata Kunci: brainstorming, mengemukakan pendapat, reward

\section{PENDAHULUAN}

Berawal dari pengamatan awal yang dilakukan oleh peneliti di MAN Cirebon 1 di kelas XI IPS 4 ada empat masalah yang terjadi dalam kelas tersebut. Yaitu : kurang antusiasnya para siswa dalam mengikuti pembelajaran sejarah, kurang responnya siswa ketika memberikan tanggapan dan sanggahan, siswa kurang aktif untuk bertanya dan menjawab pertanyaan guru dan pembelajaran juga masih menggunakan pendekatan teacher center. Untuk lebih jelasnya masalah-masalah diatas akan dipaparkan sebagai berikut: 
Satu, kurangnya antusias dari para siswa dalam mendengarkan dan menyimak penjelasan dari guru terkait materi yang disampaikan. Dua, pada saat siswa diberikan kesempatan untuk bertanya, memberikan tanggapan dan sanggahan terhadap suatu peristiwa atau materi hanya ada dua sampai tiga orang yang berpendapat dan mengajukan pertanyaan, sedangkan siswa yang lainnya hanya diam dan memperhatikan. Bertanya merupakan salah satu cara untuk mendapatkan informasi, dan dengan bertanya siswa akan lebih memahami pembelajaran. Menurut Hasyimi (2001: 247) menyatakan bahwa "bertanya adalah kunci ilmu pengetahuan karena bertanya merupakan bentuk dari usaha menjawab pertanyaan yang diajukan oleh dirinya sendiri. Oleh karena itu, dengan bertanya siswa akan mendapatkan pengetahuan baru yang tadinya mereka tidak ketahui.

Tiga, pada saat siswa diminta untuk menjawab pertanyaan yang dilontarkan oleh guru, sebagaian besar dari siswanya hanya diam dan sebagian lagi hanya membuka buku paket yang ada didepan mejanya. Sehingga, guru harus menjawab pertanyaannya sendiri. padahal siswa sudah mempunyai buku sumber. Tetapi, siswa kurang memanfaatkan buku sumbernya dengan baik. Setelah peneliti mewawancarai sebagaian siswa dari kelas tersebut ada dua faktor yang membuat siswa itu enggan untuk bertanya. Pertama siswa itu takut pertanyaannya di tertawakan oleh temannya. Kedua siswa itu takut pertanyaannya salah.

Empat, pembelajaran juga masih menggunakan pendekatan teacher center yang hanya berpusat pada guru sehingga tidak memberikan kesempatan siswa berperan aktif yang mengakibatkan siswa cepat bosan dalam belajar karena pada saat pembelajaran merasa menoton dengan memposisikannya hanya penerima ilmu saja. Terbukti dalam pembelajaran dikelas XI IPS 4 ini sebenarnya guru menjelaskan materi sudah jelas, guru menjelaskan langsung keinti materi dan ketika peneliti menanyakan ke beberapa murid dikelas tersebut, mereka sebagian besar berpendapat ketika guru tersebut mengajar, mereka mengerti apa yang dijelaskan tetapi mereka merasa bosan dengan metode yang digunakan guru dan mereka sudah berpikiran (sugesti) bahwa pelajaran sejarah itu membosankan.

Dari masalah tersebut dapat terlihat adanya masalah dalam kelas XI IPS 4 seharusnya pembelajaran sejarah adalah pembelajaran yang menyenangkan, pembelajaran yang menuntut siswanya aktif. Selain itu guru juga seharusnya lebih beragam menggunakan metode pembelajaran agar siswa di dalam kelas tidak bosan. Dalam kaitannya dengan metode guru harus memilih beberapa metide yang menuntus siswanya untuk aktif. Salah satu metode yang menggunakan tekhnik student center dan mendorong siswa untuk mengemukakan argumentasinya secara aktif yaitu metode pembelajaran braisntorming. Menurut Karwati (dalam Rosmiati, 2013: 18) metode brainstorming yaitu memberikan kesempatan kepada siswa untuk mampu menampilkan kemandirian serta pengarahan diri, memiliki keterbukaan dan keutuhan diri dalam memilih alternatif tindakan yang terbaik, mampu menyampaikan pendapat dan mengaktualisasikan diri dalam memecahkan suatu masalah serta mampu menghargai pendap orang lain. Metode brainstorming ini memberikan keleluasaan siswa untuk mengemukakan argumennya dan memecahkan suatu masalah serta mampu menghargai 
pendapat orang lain. Metode ini betujuan untuk mengumpulkan gagasan atau pendapat dalam rangka menentukan dan memilih berbagai pernyataan sebagai jawaban terhadap pertanyaan yang berkaitan dengan pembelajaran.

Penggunaan metode curah gagasan (brainstorming) dalam pembelajaran sejarah ini lebih diarahkan untuk mengajarkan daya krtitis siswa dalam mengemukakan pendapat dan untuk mengembangkan pengetahuan dan wawasan. Dalam metode ini siswa dituntut lebih aktif dalam mengemukakan pendapatnya lebih luas mendapat pengetahuan dan mengupayakan agar hasil belajar dapat bertahan lama dikuasai siswa.Konsep metode curah gagasan (brainstorming) terkandung makna suatu upaya menjadikan proses belajar mengajar menarik dan bisa mendorong siswa aktif dalam belajar dan mengemukakan pendapat. Untuk menjadikan proses belajar mengajar yang demikian, guru dituntut memikirkan, melaksanakan langkah-langkah yang memberi kemudahan bagi siswa agar dapat belajar secara aktif guna mencapai tujauan pengajaran secara efektif.

- Rumusan masalah

Berdasarkan Latar Belakang masalah yang telah diuraikan sebelumnya, maka rumusan masalah dalam penelitian ini adalah:

Bagaimana penerapan metode pembelajaran curah gagasan (brainstorming) untuk meningkatkan kemampun mengemukakan pendapat siswa dikelas XI IPS 4 MAN Cirebon 1.

Agar penelitianinimencapai sasaran sesuai dengan tujuan yang diharapkan, maka penulis memfokuskan kajian penelitian ini, maka rumusan permasalahan tersebut dibuat menjadi pertanyaan penelitian yaitu sebagai berikut:

o Bagaimana merencanakan pembelajaran sejarah untuk meningkatkan kemampuan mengemukakan pendapat siswa melalui metode curah gagasan (brainstorming) di kelas XI IPS 4 MAN Cirebon 1?

o Bagaimana proses untuk meningkatkan kemampuan mengemukakan pendapat melalui metode curah gagasan (brainstorming) dalam pembelajaran sejarah siswa di kelas XI IPS 4 MAN Cirebon 1?

o Bagaimana hasil peningkatan dalam mengemukakan pendapat setelah diterapkannya metode curah gagasan (brainstorming) dikelas XI IPS 4 MAN Cirebon 1?

o Solusi apa yang dikembangkan untuk mengatasi kendala guru dalam penerapan metode curah gagasan (brainstorming) pada pembelajaran Sejarah untuk meningkatkan kemampuan mengemukakan pendapat siswa di kelas XI IPS 4 MAN Cirebon 1?

- Tujuan penelitian

o Menambah wawasan serta keterampilan dalam menerapkan metode pembelajaran pada kegiatan belajar mengajar selanjutnya.

o Meningkatkan kemampuan berpendapt siswa menggunakan metode curah gagasan (brainstorming)

o Memperbaiki permasalahan pembelajaran yang dihadapi dan menambah wawasan serta keterampilan pembelajaran yang dapat meningkatkan hasil belajar siswa untuk meningkatkan mutu pembelajarannya. 
Metode brainstorming

Menurut Roestiyah (2008:73) metode brainstorming yaitu teknik mengajar yang dilakukan guru dengan cara melontarkan suatu masalah ke kelas oleh guru, kemudian siswa menjawab, menyatakan pendapat, atau memberi komentar sehingga memungkinkan masalah tersebut berkembang menjadi masalah baru. Secara singkat dapat diartikan sebagai satu cara untuk mendapatkan banyak/berbagai ide dari sekelompok manusia dalam waktu yang singkat. Sedangkan menurut Rawlinson (1977:27) brainstorming adalah cara untuk mendapatkan banyak ide dari sekelompok manusia dengan cara yang singkat. dari dua pendapat tersebut dapat disimpulkan bahwa dengan metode brainstorming ini siswa dilatih untuk mencari, menemukan dan mengemukakan gagasannya sebanyak mungkin dalam proses pembelajaran.

Metode ini melatih keaktifan siswa dalam bertanya dan mengolah pertanyaan sehingga mendorong siswa untuk berpartisipasi dalam proses pembelajaran. Metode ini bertujuan untuk mengumpulkan gagasan atau pendapat dalam rangka menentukan dan memilih berbagai pernyataan sebagai jawaban terhadap pertanyaan yang berkaitan dengan pembelajaran. Dengan diterapkannya metode ini maka akan terjadi proses pembelajaran yang lebih aktif dengan gagasan-gagasan yang muncul dari para siswa.

Adapun langkah-langkah dari penerapan metode brainstorming ini menurut Rawlinson (1977:35)

o Menjelaskan persoalan, guru mengangkat dan menjelaskan permasalahan yang diangkat kemudian menjelaskan cara siswa berpartisipasi dalam pembelajaran tersebut.

o Merumuskan kembali persoalan, guru menjelaskan kembali persoalan dan siswa merumuskan pertanyaanpertanyaan yang diajukan.

o Mengembangkan ide unik, maksudnya mengembangkan ide-ide yang inovatif dan diluar fariasi kebiasaan yang mungkin bisa dikembangkan.

o Mengevaluasi ide yang dihasilkan, guru dan siswa mengevaluasi ide yang telah terkumpul dan menyimpulkannya.

Mengemukakan Pendapat

Menurut Effendi (dalam Suprihatna, 2013:14) pendapat merupakan respon yang diberikan seseorang yaitu komunikan kepada komunikator yang sebelumnya telah memberikan pertanyaan. Menurut Anindawati (2013:4) menjelaskan bahwa mengemukakan pendapat adalah kemampuan menyampaikan gagasan atau pikiran secara lisan yang logis tanpa paksaan atau kehendak sendiri serta menggunakan bahasa yang baik.Pendapat diatas sejalan dengan pendapatnya Parera. Menurut Parera (1987:185) mengemukakan pendapat adalah kemampuan menggunakan bahasa dengan baik, tepat dan seksama. Sebagaimana dikemukakan oleh Paul B. Dierich (dalam Hamalik, 2008: 172) bahwa berpendapat adalah salah satu kegiatan yang harus ada dalam aktivitas pembelajaran siswa, kegiatan siswa mengemukakan pendapat ini tergolong dalam kegiatan lisan (oral). Mengemukakan pendapat adalah salah satu yang mencerminkan siswa aktif dalam proses belajar di kelas.

Keterampilan mengemukakan pendapat dalam pembelajaran sejarah ini yaitu :

o Mengidentifikasi pertanyaan 
Pada tahapan ini siswa diarahkan untuk mengidentifikasi suatu pertanyaan. Tahapan dari mengidentifikasi pertanyaan tersebut meliputi : siswa mengamati pertanyaan yang diberikan oleh guru, siswa mencari maksud/tujuan dari pertanyaan yang diajukan. Kemudian setelah siswa menemukan maksud dan tujuan dari pertanyaan yang diajukan tersebut siswa diharapkan mampu mengemukakan pendapat dengan menjawab pertanyaan tersebut

\section{o Mencari ide atau gagasan}

Pada tahapan ini siswa mencari ide atau gagasan untuk dijadikan pendapat. Tahap pencarian ide atau gagasan tersebut diperoleh dari berbagai sumber referensi seperti buku, artikel ataupun media lain yang dapat dijadikan sumber rujukan.

o Menemukan ide atau gagasan

Pada tahapan ini siswa diarahkan agar mampu menemukan ide atau gagasan dari berbagai sumber tersebut yang nantinya akan digunakan siswa dalam berpendapat.

o Merumuskan pendapat

Pada tahapan ini siswa diarahkan untuk menyusun atau merumuskan suatu pendapat berdasarkan ide atau gagasan yang diperoleh dari berbagai sumber.

o Menyampaikan pendapat

Pada tahapan ini siswa mengemukakan pendapatnya berdasarkan ide atau gagasan yang diperoleh dari berbagai sumber.

\section{METODOLOGI PENELITIAN}

Peneliti akan menggunakan metode Penelitian Tindakan Kelas (PTK) atau Classroom Action Research (CAR). Desain Penelitian yang dipakai oleh penulis adalah desain penelitian model Kemmis dan Mc Taggart karena desain model ini sangat sederhana dan cocok apabila diterapkan pada penelitian ini, yang ditujukan untuk menghindari rasa bosan siswa terhadap metode brainstorming. Ada empat tahapan dalam desain penelitian yaitu : 1. Perencanaan, 2. Pelaksanaan, 3. Pengamatan dan 4. Refleksi. Langkah-langkah penelitian tersebut digambarkan sebagai berikut

Penelitian tindakan kelas ini dilaksanakan di MAN CIREBON 1, subjek penelitian adalah para siswa kelas XI IPS 4 MAN Cirebon 1 tahun ajaran $2014 \backslash 2015$ berjumlah 44 siswa dengan 31 orang siswi dan 13 orang siswa. Pada penelitian tindakan kelas ini peneliti akan berkolaborasi dengan guru Sejarah MAN 1 Cirebon yaitu Dra. N. Tati Kusmiyati dan yang menjadi mitra yaitu Muh An'um dan Eka Puspita Sari.

\section{Instrumen Penelitian}

Pada penelitian ini instrumen utama yang digunakan adalah peneliti. Manusia sebagai instrumen utama dibantu oleh alat-alat. Berikut ini adalah alat bantu yang peneliti gunakan dalam penelitian ini :

\section{o Pedoman Observasi}

Dengan adanya panduan observasi ini maka peneliti mengamati dan mencatat apa yang terjadi ketika pembelajaran berlangsung. Data yang ingin diperoleh dalam penelitian ini yaitu gagasan yang diperoleh oleh siswa dan keaktifan dalam mengemukakan pendapat.

\section{o Pedoman wawancara}

Pedoman wawancara ini merupakan kisi-kisi pertanyaan yang disiapkan oleh peneliti sebelum melakukan wawancara. Jawaban dari guru yang diwawancarai 
dengan wawancara semi terstruktur ini dijadikan refleksi bagi peneliti untuk perbaikan tindakan selanjutnya.

o Lembar Penilaian Diri

Lembar penialaian diri digunakan untuk mengetahui partisipasi siswa dalam proses pembelajaran dan untuk memperbaiki proses pembelajaran berikutnya. Siswa diminta untuk menilai sikapnya dalam proses itu.

o Dokumentasi

Dokumentasi yang digunakan adalah perangkat dokumen resmi yang digunakan selama proses belajar mengajar berlangsung seperti silabus dan rencana pelaksanaan pembelajaran. Selain itu, dokumen penunjang seperti tugas-tugas siswa catatan tentang kehadiran dan aktivitas siswa dikelas juga digunakan sebagai dokumentasi

\section{o Catatan Lapangan}

Pada catatan lapangan, peneliti dan mitra dapat memperoleh gambaran perihal proses pembelajaran. dalam catatan lapangan juga dapat dilihat sudah sejauh mana permasalahan dalam pembelajaran teratasi. Hasil catatan lapangan didiskusikan dengan mitra. Dalam catatan lapangan mitra mencatat segala sapek yang selama proses pembelajaran berlangsung dan catatan tersebut sebagai sumber yang akan peneliti gunakan dalam penelitian tindakan kelas .

\section{Teknik Pengumpulan Data}

Data yang diperlukan peneliti dapat diperoleh dari siswa, guru, mitra dan pihak lain yang relevan dengan penelitian ini. Pada tahap ini peneliti memperoleh data dari tindakan-tindakan yang dilakukan peneliti pada saat pembelajaran.Kegiatan yang diamati pada penelitian ini adalah kinerja siswa dalam mencari ide, mengumpulkan ide dan mengemukakan pendapatnya. Adapun teknik pengumpulan data yaitu dengan beberapa cara :

\section{o Observasi}

Pada penelitian ini, dilakukan observasi penilaian untuk menilai seberapa banyak ide yang dikumpulkan oleh siswa dan keaktifan siswa ketika mengemukakan pendapat. Untuk melihat guru dalam proses pembelajaran dan penerapan metode brainstorming digunakan lembar observasi aktivitas guru dan menilai kontribusi siswa pada proses pembelajaran digunakan penilaian diri kepada siswa setelah proses pembelajaran berlangsung. Untuk melihat aktivitas keseluruhan dan melihat peristiwa yang terjadi dikelas peneliti menggunakan catatan lapangan.

Kolaborasi anatara mitra dengan peneliti sangat penting dalam keberhasilan penelitian. Maka perlu adanya kerjasama dan saling berdiskusi dari mulai perencanaan, penerapan dan hasil pembelajaran. dari hasil pengamatan ini akan diperoleh kesimpulan dan menentukan langkah penelitian berikutnya.

\section{o Wawancara}

Wawancara dalam penelitian ini digunakan untuk mengetahui tanggapan guru terutama mengenai penerapan metode brainstorming terhadap kemampuan mengemukakan pendapat siswa. pedoman wawancara digunakan untuk mendapatkan data secara kualitatif yang diperoleh untuk bahan analisi pada tahap selanjutnya terutama untuk mengetahui aktivitas siswa selama penerapan metode brainstormng. 
o Studi Dokumentasi

Pada penelitian ini yaitu rencana pelaksanaan pembelajaran, foto-foto kegiatan pembelajaran, lembar penilaian keaktifan mengemukakan pendapat dan ide-ide yang didapatkan oleh siswa.

Analisis Data Hasil Penelitian

Dalam penelitian tindakan kelas (PTK) analisis data sudah dilakukan sejak awal meliputi semua aspek penelitian. Sedangkan cara-cara untuk menguji tingkat validasi dalam PTK akan dipaparkan sebagai berikut:

\section{o Member check}

Pada penelitian ini peneliti memeriksa kembali informasi atau data-data yang telah diperoleh selama proses penelitian berlangsung.

\section{o Saturation}

pada proses ini, peneliti mengumpulkan data dari setiap tindakan dan ketika data itu sudah berada ditik jenuh maka penelitian itu dianggap telah selesai.

\section{o Expert Opinion}

Pada penelitian ini exspert opinion yang dilakukan sejalan dengan pendapat di atas bahwa peneliti akan meminta kepada orang yang dianggap ahli dalam hal ini adalah pembimbing penelitian ini untuk memeriksa semua tahapan-tahapan kegiatan penelitian dan memberikan arahan atau judgements terhadap masalah-masalah penelitian yang dikaji.

\section{o Audit Trail}

Peneliti juga memeriksa catatancatatan yang ditulis oleh peneliti atau pengamat mitra penelitian lainnya". Hal ini berguna, apabila peneliti akan memperoleh informasi kembali atau data yang ada, atau waktu mempersiapkan laporan. Audit trail dapat dilakukan oleh kawan sejawat peneliti, yang memiliki pengetahuan dan keterampilan melakukan penelitian tindakan kelas yang sama.

\section{HASIL PENELITIAN DAN PEMBAHASAN}

$\begin{array}{lrr}\begin{array}{l}\text { Perencanaan } \\ \text { Brainstorming Penerapan }\end{array} & \begin{array}{r}\text { Metode } \\ \text { pelaksanaan }\end{array} \\ \text { dalam }\end{array}$

Perencanaan yang peneliti laksanakan dalam menerapkan metode brainstorming untuk meningkatkan kemampuan mengemukakan pendapat siswa dikelas XI IPS 4 MAN Cirebon 1, akan peneliti deskripsikan sebagai berikut:

Pada observasi awal akan dijelaskan kembali mengenai hasil dari pengamatan peneliti yang termasuk ke dalam kegiatan pra penelitian di kelas XI IPS 4 MAN Cirebon 1. Peneliti melakukan pra penelitian selama 3 kali. Berbagai masalah yang terlihat di sekolah ini terutama di kelas XI IPS 4 meliputi pertama, kurangnya antusias dari para siswa dalam mendengarkan dan menyimak penjelasan dari guru terkait materi yang disampaikan. Kedua, kurangnya inisiatif siswa untuk mengemukakan pendapatnya, ketika guru memberikan kesempatan kepada siswa untuk mengajukan pertanyaan. Ketiga, pembelajaran masih menggunakan pendekatan teacher center yang hanya berpusat pada guru sehingga tidak memberikan kesempatan siswa berperan aktif.

Berdasarkan hasil refleksi peneliti terkait hasil kegiatan observasi pra penelitian, dan diskusi peneliti dengan guru mitra Dra. N. Tati Kusmiyati, maka rencana tindakan yang akan dilakukan dalam penelitian ini diantaranya mengenai 
rencana pelaksanaan pembelajaran yang mengacu kepada kurikulum 2006, metode pembelajaran, persiapan materi, penilaian dan penugasan. Peneliti berencana akan menerapkan metode brainstoming. Brainstorming disini dipilih karena memenuhi kriteria yang diperlukan guna memecahkan berbagai permasalahan yang telah ditemukan di kelas XI IPS 4 selama kegiatan observasi awal dilaksanakan.

Hal selanjutnya yang dibahas yaitu mengenai pembuatan silabus setelah membuat silabus peneliti membuat RPP yang mana sekolahinimasih menggunakan kurikulum 2006 atau KTSP. Perencanaan tentang berapa banyak siklus yang akan dilaksanakan dalam penelitian ini juga ditentukan bersama guru mitra. Peneliti menjelaskan bahwa dalam penelitian tindakan kelas, tidak dapat dipastikan kapan siklus harus berhenti, dan kapan siklus mencapai titik jenuh. Maka dari itu, peneliti tidak dapat memastikan akan sampai berapa siklus, tergantung seberapa siswa memahami metode brainstorming

Mengenai pembagian kelas penelitian, setelah melakukan diskusi maka diputuskan penelitian diadakan di kelas XI IPS 4. Jadwal masuk kelas akan dilaksanakan pada hari Senin pada jam 09.00-09.40 WIB dikarenakan ada jeda istirahat maka dilanjutkan pada jam 10.00-10.40. Sedangkan materi yang harus disampaikan disesuaikan dengan materi yang belum disampaikan di kelas XI IPS 4 .

Deskripsi Data Hasil Lembar Observasi Kemampuan Mengemukakan Pendapat

Pengolahan data secara keseluruhan selama pelaksanaan siklus tindakan dilakukan dari hasil observasi siswa ini dilakukan untuk mengetahui seberpa besar tingkat kemampuan mengemukakan pendapat. Tahap pertama yang dilakukan oleh peneliti dalam mengolah data yaitu menjumlahkan indikator secara keseluruhan yang telah didpat oleh siswa dan menghitung presentase dari setiap siklusnya. Berikut hasil penjumlahan skor setiap siklusnya.

\section{Grafik Kemampuan Mengemukakan Pendapat Pada Setiap Siklusnya}

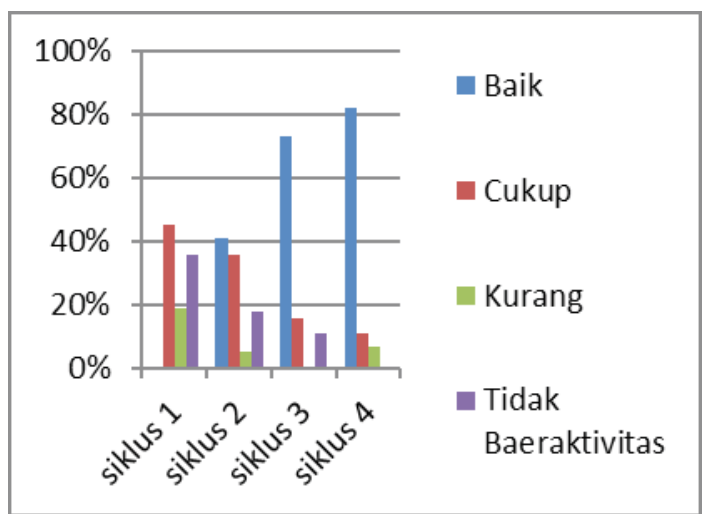

Tabel Presentase Kemampuan Mengemukakan Pendapat Siswa pada Setiap Siklusnya

\begin{tabular}{|l|l|l|l|l|}
\hline Hasil & \multicolumn{4}{|c|}{ Aspek yang dinilai } \\
\cline { 2 - 5 } $\begin{array}{l}\text { Presen } \\
\text { tse }\end{array}$ & Baik & Cukup & Kurang & $\begin{array}{l}\text { Tidak } \\
\text { berak } \\
\text { Tivitas }\end{array}$ \\
\hline $\begin{array}{l}\text { Siklus } \\
1\end{array}$ & - & $45 \%$ & $19 \%$ & $36 \%$ \\
\hline $\begin{array}{l}\text { Siklus } \\
2\end{array}$ & $41 \%$ & $36 \%$ & $3 \%$ & $18 \%$ \\
\hline $\begin{array}{l}\text { Siklus } \\
3\end{array}$ & $73 \%$ & $16 \%$ & - & $11 \%$ \\
\hline $\begin{array}{l}\text { Siklus } \\
4\end{array}$ & $82 \%$ & $11 \%$ & $7 \%$ & - \\
\hline
\end{tabular}

Berdasarkan data di atas menjelaskan bahwa kemampuan siswa pada setiap siklusnya mengalami perkembangan dengan baik. Sesuai dengan jumlah siklusnya yaitu empat siklus maka ada empat kategori yang bisa diterjemahkan 
dari tabel di atas. Menurut data di atas bahwa hasil presentase kemampuan mengemukakan pendapat yang paling tinggi pada siklus satu berada pada kategori "cukup" yaitu 45\%. Pada kategori ini siswa hanya mengemukakan pendapatnya pada apa yang ditulis dibuku paket, dan masih sedikit yang mengemukakan pendapatnya karena pada tahap ini guru dan siswa masih dalam tahap adaptasi dalam pembelajaran sejarah dengan metode brainstorming.

Kategori yang kedua yaitu "Baik", data observasi siswa pada siklus yang kedua. Berdasarkan data tersebut bahwa presentase yang paling tinggi terdapat pada kategori baik yaitu sebesar $41 \%$ yang sudah mengalami kenaikan yang signifikan. Pada siklus ini guru dan siswa sudah bisa menyesuaikan dengan metode brainstorming dalam pembelajaran sejarah tersebut. Disini guru sudah berusaha lebih memperhatikan RPP atau skenario dalam pembelajaran, guru juga menyiapkan pertanyaan-pertanyaan yang menarik untuk cari jawabannya oleh siswa dan media yang digunakan lebih menarik dibandingkan siklus sebelumnya. Sehingga siswa lebih antusias dibandingkan dengan siklus sebelumnya.

Kategori yang ketiga "Baik",
data observasi siswa pada siklus ketiga. Berdasarkan data tersebut bahwa presentase yang paling tinggi yaitu pada kategori baik sebesar $73 \%$ siswa mengemukakan gagasannya dan mengalami perkembangan dalam kemampuan mengemukakan pendapatnya. Siswa pada siklus ini mengalami peningkatan. Karena disini guru mempersiapkan skenario pembelajaran lebih matang seperti materi dan pertanyaan-pertanyaan yang menarik. Selain itu juga guru mempersiapkan dengan baik media yang digunakan sehingga siswa lebih antusia lagi dalam proses pembelajaran.

Kategori yang keempat "Baik", data observasi siswa pada siklus keempat atau terakhir berdasarkan data tersebut bahwa presentase paling tinggi yaitu pada kategori baik sebesar $82 \%$. Pada siklus keempat ini peneliti dan observer ingin mengetahui sejauh mana perubahan yang terjadi jika dilakukan siklus sekali lagi, hasil observasi pada siklus keempat ini mengalami sedikit peningkatan yang tidak terlalu signifikan dari siklus sebelumnya. Maka peneliti dan guru mitra memutuskan bahwa pelaksanaan tindakan salam peneilitian ini hanya sampai empat kali.

Deskripsi Data Hasil Observasi Aktivitas Guru Pada Saat Penerapan Metode Brainstorming

Pengolahan data secara keseluruhan selama pelaksanaan siklus tindakan dilakukan dari hasil observasi aktivitas guru. Hal tersebut bertujuan untuk mengetahui sejauh mana usaha peneliti dalam megembangkan kemampuan mengemukakan pendapat siswa dikelas XI IPS 4. Data hasil observasi guru ini diambil dari deskripsi disetiap siklusnya :

Berdasarkan hasil pengamatan dari setiap siklusnya hasil observasi guru dalam menerapkan metode brainstorming mengalami peningkatan, hal tersebut dapat ditunjukan dalam siklus I observasi guru secara keseluruhan berada pada kategori "baik", terlihat dari dua puluh satu komponen sembilan komponen sudah berada pada kategori baik. pada siklus kedua observasi guru secara keseluruhan berada pada kategori "baik", adanya peningkatan dari siklus sebelumnya komponen baik pada siklus dua yaitu sebesar tiga belas komponen sudah berada pada kategori baik. jika dilihat 
dari perubahan siklus I hingga siklus II terdapat perubahan yang cukup baik. Hal ini disebabkan peneliti belum belajar dari kekurangan-kekurangan mengajarnya disiklus I dalam menerapkan metode brainstorming

Pada siklus III ini secara keseluruhan berada pada kategori "sangat baik", pada siklus ini adanya peningkatan yang signifikan. Kategori baik pada siklus ini yaitu delapan belas komponen. Pada siklus IV data yang diperoleh tidak mengalami peningkatan yang signifikan, pada siklus ini secara keseluruhan berada pada kategori "sangat baik".kategori baik berjumlah sembilan belas komponen. Dari data-data yang diperoleh diatas hasil keseluruhan dari setiap siklusnya berada pada kategori "sangat baik".

Deskripsi Data Hasil lembar Observasi Penilaian diri siswa

Pengolahan data secara keseluruhan selama pelaksanaan siklus tindakan dilakukan dari hasil lembar observasi siswa ini dilakukan untuk mengukur seberapa besar tingkat kontribusi siswa dalam proses pembelajaran dengan menggunakan metode brainstorming. berikut hasil kontribusi siswa pada setipa siklusnya.

\section{Hasil kontribusi siswa pada setiap siklusnya}

\begin{tabular}{|l|l|c|}
\hline $\begin{array}{l}\text { Pelaksanaan } \\
\text { siklus }\end{array}$ & Skor & Nilai rata-rata \\
\hline I & 746 & 68 \\
\hline II & 921 & 83 \\
\hline III & 991 & 90 \\
\hline IV & 998 & 92 \\
\hline
\end{tabular}

Adapun kategori yang peniliti kembangkan untuk lembar penilaian diri siswa adalah sebagai berikut :
100-90 : Sangat berkontribusi

89-80 : Berkontribusi

79-70 : Cukup Berkontribusi

69-60 : : Tidak berkontribusi

Berdasarkan penyajian tabel, dapat dipeoleh hasil bahwa kontribusi siswa pada setiap siklus mengalami peningkatan, dari tabel diketahui skor kesuluruhan disetiap siklus. Pada siklus satu, kontribusi siswa memperoleh 746, untuk siklus dua kontribusi siswa meningkat menjadi 921, kontribusi pada siklus tiga juga mengalami peningkatan yaitu 991, namun kontribusi siswa pada siklus empat mengalami peningkatan yang tidak signifikan yaitu sebesar 998 .

Kendala-Kendala yang Dihadapi Oleh Guru Sejarah Dalam Mengembangkan Metode Braisntorming Untuk Meningkatkan Kemampuan Mengemukakan Pendapat

Kendala yang dihadapi guru ketika menerapkan metode brainstorming dapat dipaparkan sebagai berikut :

o Siswa harus selalu dimotivasi ketika ingin mengemukakan pendapatnya

o Siswa terlalun bergantung pada guru. Masih tepaku pada paradigma guru sebagai pusat pembelajaran atau guru yang harus dominan (teacher center)

o Guru harus lebih matang dalam membuat skenario pembelajaran

o Guru harus lebih menarik dalam membuat pertanyaan agar siswa lebih antusias

o Media yang digunakan harus semenarik mungkin agar siswa lebih tertarik dalam proses pembelajaran

o Siswa masih terpaku pada satu 
sumber yaitu buku paket

Maka setelah terdapat beberapa kendala yang terdapat dalam penerapan metode brainstorming untuk meningkatkan kemampuan mengemukakan pendapat. Peneliti berupaya dan berusaha untuk mengatasi kendala-kendala yang dihadapi. Solusi masalah sebagai berikut :

o Guru selalu memotivasi siswa agar siswanya berkompetisi dalam mengemukakan pendapatnya

o Siswa harus dibiasakan dengan pembelajaran yang aktif (student center)

o Perlu rencana pembelajaran yang matang agar proses pembelajaran berjalan dengan baik

o Guru harus selalu memberi motivasi kepada siswa agar mereka antusias dalam membaca materi pembelajaran.

o Guru harus membuat media semenarik mungkin agar siswa lebih antusias dalam proses pembelajaran.

o Guru harus menyediakan sumbersumber yang relevan untuk menunjang dalam proses pembelajaran.

Analisis Kemampuan Mengemukakan Pendapat Melalui Metode Brainstorming Dalam Pembelajaran Sejarah

Penelitian tindakan kelas ini telah dilakukan oleh peneliti dan observer secara keseluruhan dalam proses pembelajaran sejarah di kelas. Berdasarkan hasil penelitian yang dilakukan oleh peneliti dengan menggunakan instrumen berupa observasi siswa, observasi guru, catatan lapangan dan studi dokumentasi. Maka didapatkan hasil bahwa penerapan metode brainstorming dapat meningkatkan kemampuan mengemukakan pendapat dalam pembelajaran sejarah, hal tersebut telah dideskripsikan dalam pembahasan siklus di atas. Pada siklus pertama masih pada kategori cukup baik karena siswa masih perlu adaptasi dengan metode brainstorming dan sumber belajar yang hanya terpaku pada buku teks.

Namun, setelah peneliti belajar dari siklus pertama, diantaranya guru memberikan motivasi dengan memberikan reward, dan membuat media yang menarik perhatian siswa. hasilnya pada siklus kedua,ketiga dan keempat kategori kemampuan mengemukakan pendapat siswa berada pada tingkatan baik. Begitupun pada hasil observasi kontribusi siswa pada siklus kedua, ketiga dan keempat berada pada tingkatan baik.

Pada siklus kedua, ketiga dan keempat sudah pada kategori baik, karena siswa antusias dalam mengidentifikasi pertanyaan, mencari ide atau gagasan, menemukan ide atau gagasan, merumuskan pendapat dan mengajukan pendapat dalam pembelajaran sejarah. Dalam penerapan metode ini, siswa lebih sering mengungkapan gagasannya hal tersebut sejalan dengan yang dikatakan Rawlinson (1977:27) brainstorming adalah cara untuk mendapatkan banyak ide dari sekelompok manusia dengan cara yang singkat. Dalam hal ini waktu yang diberikan kepada siswa dalam mengungkapkan gagasannya hanya pada saat pembelajaran sejarah saja. Sedangkan menurut Sudjana (1983:35) brainstorming adalah metode pembelajaran yang dilakukan dalam kelompok yang peserta didiknya memiliki latar belakang dan pengetahuan yang berbeda-beda. Maka Metode ini melatih keaktifan siswa dalam bertanya dan mengolah pertanyaan sehingga mendorong siswa untuk berpartisipasi dalam proses pembelajaran. 
Menurut pernyataan Rawlinson dan Sudjana di atas dapat diambil kesimpulan bahwa pembelajaran dengan menggunakan metode brainstorming akan terjadi proses pembelajaran yang lebih aktif dengan gagasan-gagasan yang muncul dari para siswa. terbukti dari setiap siklusnya terdapat peningkatan dengan menerapkan metode brainstorming. pada siklus kedua siswa sudah mengalami peningkatan yang signifikan karena siswa sangat antusia dengan pembelajaran menggunakan metode brainstoming. Pada siklus ketiga dan keempat pun siswa mengalami peningkatan kembali karena siswa sudah semakin terbiaa denga diterapkannya metode brainstoming dalam pembelajaran sejarah.

Selain itu, melalui metode brainstorming ini, siswa dilatih untuk mencari, menemukan, mengolah sumber informasi tersebut menjadi ide atau gagasan yang akan digunakannya dalam mengemukakan pendapat. Disamping itu siswa juga dituntut untuk mampu bekerja secara individu, sehingga kemampuan siswa secara individu dapatdiamatidengan jelas. Hal tersebut senada dengan pendapat yang dikemukakan oleh Nasution (2010:7) menyatakan "pembelajaran merupakan proses mengolah dan mengembangkan tingkah laku subyek belajar dalam rangka pembentukan pribadinya". Proses tukan menukar pendapat, menanggapi suatu pendapat orang lain dan menambahkan suatu pendapat merupakan aktivitas yang baik bagi perkembangan intelektual siswa

\begin{tabular}{lrr}
\multicolumn{1}{c}{ Menurut } & Parera $\quad(1987: 185)$ \\
mengemukakan & pendapat adalah \\
kemampuan & menggunakan bahasa \\
dengan baik, tepat dan seksama. Berkaitan \\
dengan tujuan & metode brainstorming \\
bahwa semakin & sering mengemukakan \\
pendapatnya & maka pendapatnya
\end{tabular}

akan semakin baik dan bahasa yang disampaikannya akan semakin baik dan berkualitas. Hal tersebut terbukti dengan penelitian yang dilakukan peneliti bahwa kemampuan mengemukakan pendapat pada siklus kedua, ketiga dan keempat kemampuan mengemukakan pendapat berada pada kategori baik

Implikasi penerapan Kemampuan Mengemukakan Pendapat Melalui Metode Brainstorming Dalam Pembelajaran Sejarah

Dari siklus pertama sampai siklus keempat respon siswa dalam penialain diri terkait dengan pendapat siwa terhadap metode brainstorming dalam pembelajaran sejarah di kelas XI IPS 4 menunjukan bahwa metode tersebut dapat meningkatkan kemampuan mengemukakan pendapat siswa. Selain itu, pembelajaran sejarah dengan menggunakan metode brainstorming menjadi lebih menyenangkan, siswa lebih berperan secara aktif dalam kegiatan pembelajaran dan siswa jadi lebih fokus. Siswa juga dapat mengemukakan pendapatnya lebih leluasa sehingga kemampuan siswa dalam menyampaikan pendapat dapat terlihat.

Penggunaan metode brainstorming pada saat proses pembelajaran, memperlihatkan keaktifan siswa pada saat mengemukakan pendapat, serta respon siswa dilihat dari penilaian diri siswa, yang pada umunya menunjukan ketertarikan atau antusias pada proses pembelajaran. Penerapan metode brainstorming dalam pembelajaran sejarah tidak hanya meningkatkan kemampuan mengemukakan pendapat siswa yang memang menjadi fokus penelitian, ternyata penerapan metode brainstoming ini dapat memberikan dampak yang lain yakni, dalam hal keaktifan siswa dan 
minat belajar terhadap pembelajaran sejarah, siswa menjadi lebih tertarik dan lebih fokus dalam pembelajaran sejarah

\section{PENUTUP}

Kesimpulan

Pertama, perencanaan penerapan metodebrainstorming dalam pembelajaran sejarah, guru sebagai peneliti berkolaborasi dengan guru mitra sebagai pengajar yang sudah berpengalaman, guru mitra juga dapat memberi masukan kepada guru sebagai peneliti. Guru mempersiapkan silabus yang nantinya sebagai acuan untuk membuat rencana pelaksanaan pembelajaran (RPP) yang disesuaikan dengan kondisi serta karakteristik siswa untuk diterapkan dalam setiap pelaksanaan tindakan, mempersiapkan materi pembelajaran, mempersiapkan media pembelajaran yang dapat menarik perhatian serta akan menimbulkan antusias dalam proses pembelajaran. Dalam setiap siklusnya peneliti menyiapkan pertanyaan-pertanyaan yang menarik agar siswa berperan aktif dalam mengemukakan pendapat, tidak hanya itu peneliti juga mempersiapkan lembar observasi siswa, lembar observasi guru dan lembar penilaian diri siswa.

Kedua, pelaksanaan metode brainstorming atau curah gagasan dalam meningkatkan kemampuan mengemukakan pendapat dilakukan setiap tindakan siklus. Pelaksanaan tindakan dalam penerapan metode brainstorming yaitu ada tiga hal yang harus dilakukan dalam pelaksanaan metode brainstorming yaitu kegiatan pembuka, kegiatan inti dan kegitan penutup. Dalam penerapan metode brainstorming pada kegiatan pembuka guru menjelaskan tata cara pembelajaran menggunakan metode brainstorming dan memberikan motivasi awal kepada siswa agar siswa termotivasi dalam pembelajaran sejarah.

Pada kegiatan inti guru memberikan pertanyaan-pertanyaan menarik yang nantinya akan dicari ide atau gagasannya oleh siswa kemudian guru memberi waktu siswa untuk mencari ide atau gagasannya dari berbagai sumber selanjutnya guru memberi kesempatan kepada siswa untuk mengemukakan gagasannya. Ketika siswa sedang mengemukakan pendapatnya guru harus menunda penilaian terhadap gagasan yang diutarakan oleh siswa hal yang dilakukan oleh guru ketika metode brainstorming ini diterapkan yaitu guru harus selalu memberikan motivasi kepada siswa agar siswa sebanyak mungkin mengemukakan pendapatnya. Setelah selesai penerapan metode brainstorming guru dan siswa bersamasama mengevaluasi pendapat yang dikemukakan oleh siswa. Pada kegiatan penutup guru dan siswa bersama-sama menyimpulkan materi secara keseluruhan kemudian guru memberikan tindak lanjut berupa tugas.

Ketiga, hasil setelah diterapkannya metode brainstorming dalam proses pembelajaran sejarah, mengalami peningkatan kemampuan mengemukakan pendapat secara bertahap pada setiap siklusnya setelah diterapkannya metode brainstorming. pada pelaksanaan tindakan I kemampuan mengemukakan pendapat siswa masih dalam kategori cukup dengan presentase $45 \%$, tetapi pada pelaksanaan tindakan II presntase katagori baik yaitu $41 \%$, pada tindakan III presentase kategori baik yaitu $73 \%$, dan pada tindakan IV presentase baik yaitu $82 \%$, sehingga pada tindakan IV kemampuan mengemukakan pendapat sudah terlihat sangat baik. Hal ini terbukti dari hasil lembar observasi pada saat proses pembelajaran, keaktifan siswa pada saat mengemukakan pendapat, serta 
respon siswa dilihat dari penilaian diri siswa, yang pada umunya menunjukan ketertarikan atau antusias pada proses pembelajaran dengan menggunakan metode brainstorming.

Dari siklus pertama sampai siklus keempat respon siswa dalam penialain diri terkait dengan pendapat siwa terhadap metode brainstorming dalam pembelajaran sejarah di kelas XI IPS 4 menunjukan bahwa metode tersebut dapat meningkatkan kemampuan mengemukakan pendapat siswa. Selain itu, pembelajaran sejarah dengan menggunakan metode brainstorming menjadi lebih menyenangkan, siswa lebih berperan secara aktif dalam kegiatan pembelajaran dan siswa jadi lebih fokus. Siswa juga dapat mengemukakan pendapatnya lebih leluasa sehingga kemampuan siswa dalam menyampaikan pendapat dapat terlihat.

Keempat, dalam penerapan metode brainstorming sebagai upaya meningkatkan kemampuan mengemukakan pendapat siswa dalam pembelajaran sejarah memang menemui beberapa kendal. Kendala yang dialami sebagian besar disebabkan karena keterbatasan waktu untuk mengeksplorasi pertanyaan dan materi pelajaran lebih mendalam, selain itu pertanyaan-pertanyaan yang menarik untuk menstimulus siswa dalam mencari gagasan dan menemukan gagasan yang sesuai dengan materi pembelajaran dan harus dapat merangsang siswa untuk mengajukan pendapatnya. Namun kendala-kendala tersebut dapat diatasi melalui upaya-upaya perbaikan yaitu dengan cara guru selalu memotivasi siswa agar siswanya berkompetisi dalam mengemukakan pendapatnya, Siswa harus dibiasakan dengan pembelajaran yang aktif (student center), perlu rencana pembelajaran yang matang agar proses pembelajaran berjalan dengan baik, guru harus selalu memberi motivasi kepada siswa agar mereka antusias dalam membaca materi pembelajaran, guru harus membuat media semenarik mungkin agar siswa lebih antusias dalam proses pembelajaran dan guru harus menyediakan sumber-sumber yang relevan untuk menunjang dalam proses pembelajaran.

Saran

Adapun saran yang ingin penulis sampaikan berkaitan dengan penerapan metode brainstoming dalam pembelajaran sejarah sebagai berikut:

o Bagi guru, metode brainstorming merupakan salah satu alternatif solusi bagi pembelajaran sejarah di kelas. Guru harus senantiasa membimbing dan memfasilitasi siswa agar lebih dominan aktif dalam proses pembelajaran. Guru harus memperjelas aturan dari metode ini, sehingga siswa lebih paham ketika melakukannya.

o Bagi sekolah, sekolah harus lebih mendukung, memfasilitasi, dan memperbaiki fasilitas yang sudah ada, sehingga guru guru lebih mudah saat mengajar di kelas. Kemudian guru juga harus mendukung metode pembelajaran yang ada selama itu berdampak positif untuk siswa.

o Bagi peneliti lebi lanjut, dalam penerapan metode brainstorming ini masih banyakkekuarangan oleh karena itu, banyak perbaikan-perbaikan yang harus dilakukan oleh penelitian selanjutnya agar penerapan metode brainstorming ini dapat diterapkan dengan semaksimal mungkin.

o Bagi peneliti, pada penelitian metode 
brainstoming ini telah meningkatkan kemampuan mengemukakan pendapat dalam pembelajaran sejarah. Siswa lebih ikut berpartisipasi dalam proses pembelajaran terutama dalam mengemukakan gagasan. Namun dalam hal ini peneliti menyadari masih banyak kekurangan dalam pelaksanaan penelitian ini. Maka peneliti berharap untuk penelitian selanjutnya, materi harus lebih dikuasai oleh guru, membuat pertanyaan semenarik mungkin agar siswa lebih termotivasi.

\section{DAFTAR PUSTAKA}

Hamalik, O. (2008). Proses Belajar Mengajar. Jakarta: PT Bumi Aksara.

Hasyimi, A.H. (2001). Mendidik Ala Rasulullah. Jakarta: Pustaka Azzam

Nasution (2010). Didaktik asas-asas mengajar. Jakarta: Bumi Aksara

Parera, J.D. (1987). Belajar Mengemukakan Pendapat. Jakarta: Erlangga

Rawlinson, JG. (1977). Berfikir Kreatif dan Brainstorming. Jakarta: Erlangga

Roestiyah. (2008). Strategi Belajar Mengajar. Jakarta: Rineka Cipta

Rosmiati, V . (2013). Penerapan Metode Pembelajaran Brainstorming Untuk Meningkatkan Kemampuan Berpikir Kritis Siswa Kelas Xi Ips 4 Di Sma Negeri Situraja (Penelitian Tindakan kelas pada mata pelajaran Geografi) Bandung. Skripsi Sarjana pada FPIPS UPI Bandung : Tidak diterbitkan.

Suprihatna, A (2013). Penerapan metode Learning Starts with A question dalam pembelajaran sejarah untuk meningkatkan kemempuan mengemukakan pendapat siswa (Penelitian Tindakan kelas di kelas XI IPS SMA Negeri Tanjung sari).Bandung. Skripsi Sarjana pada FPIPS UPI Bandung : Tidak diterbitkan 